\title{
New 1,2,3-Triazole-Appended Bis-pyrazoles: Synthesis, Bioevaluation, and Molecular Docking
}

\author{
Ashruba B. Danne, Mukund V. Deshpande, Jaiprakash N. Sangshetti, Vijay M. Khedkar, \\ and Bapurao B. Shingate*
}

Cite This: ACS Omega 2021, 6, 24879-24890

Read Online

ABSTRACT: The present work describes design of a small library of new 1,2,3-triazole-appended bis-pyrazoles by using a molecular hybridization approach, and the synthesized hybrids were evaluated for their antifungal activity against different fungal strains, namely, Candida albicans, Cryptococcus neoformans, Candida glabrata, Candida tropicalis, Aspergillus niger, and Aspergillus fumigatus. All the compounds exhibited broad-spectrum activity against the tested fungal strains with excellent minimum inhibitory concentration values. The molecular docking study against sterol $14 \alpha$-demethylase (CYP51) could provide valuable insights into the binding modes and affinity of these compounds. Furthermore, these compounds were also evaluated for their antioxidant activity, which also resulted in promising data.

\section{INTRODUCTION}

Candidiasis is normally a harmless fungal infection affecting the skin and mucous membranes of the mouth or intestines. Invasive fungal infections are life-threatening and mostly caused by opportunistic fungal pathogens such as Candida species, Aspergillus fumigatus, and Cryptococcus neoformans. ${ }^{2}$ Candida albicans and other nonalbicans species are the infectious agents in immunocompromised patients, and they cause morbidity and mortality. ${ }^{3}$ Fluconazole is preferred as first-line antifungal therapy. ${ }^{3}$ The dependence on existing antifungal drugs such as azoles (fluconazole, voriconazole, itraconazole, and posaconazole), polyenes (amphotericin B), allylamines (terbinafine and naftifine), and echinocandins (caspofungin and micafungin), has resulted in the development of drug-resistant fungal strains. ${ }^{4}$ The current status of fungal infections and the drawbacks of existing drugs demand for the development of more effective and safe antifungal agents with novel targets.

Pyrazole is an important pharmacophore scaffold ${ }^{5}$ and found in various drugs, viz., betazole (histamine $\mathrm{H}_{2}$ receptor agonist), rimonabant (anorectic antiobesity), CDPPB (antipsychotic), lonazolac, difenamizole, celecoxib (anti-inflammatory), and fezolamine, which is an antidepressant drug. Pyrazole exhibits a wide range of pharmacological activities such as antioxidant, ${ }^{6}$ antifungal, ${ }^{7}$ antitubercular, ${ }^{8}$ antimalarial, ${ }^{9}$ antiproliferative, ${ }^{10}$ anticancer, ${ }^{11}$ anti-inflammatory, ${ }^{12}$ and antimicrobial ${ }^{13}$ activities. In addition to this, heterocyclic hybrids of pyrazole derivatives have been reported r-16 $^{14}$ as they display an antifungal activity profile.

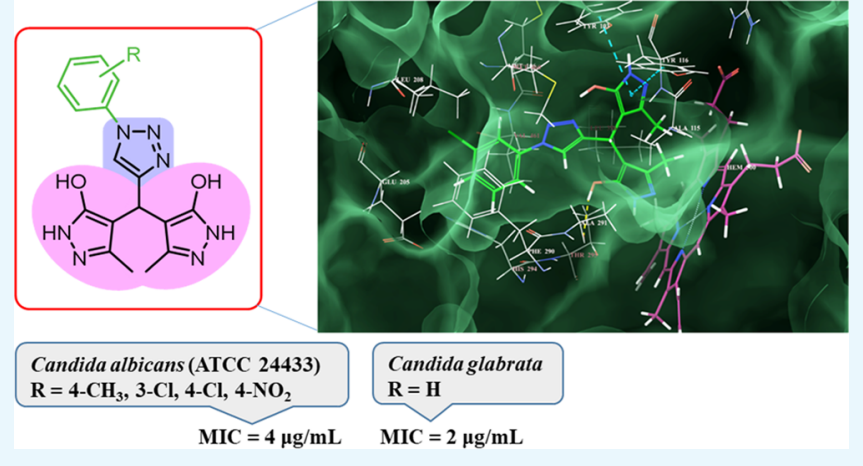

Several researchers have paid attention toward the synthesis of bis-pyrazole molecules ${ }^{17}$ because of their diverse biological activities; the representative structures of the molecules 1-7 are shown in Figure 1. Sujatha and co-workers reported ${ }^{18}$ the facile synthesis of bis-pyrazoles $\mathbf{1}$ and evaluated their in vitro antiviral activity. The pyrazole-based molecules 2 were synthesized and evaluated for their antimicrobial activity. ${ }^{19}$ Farag et al. reported ${ }^{20} \mathrm{~N}$-phenylpyrazoles 3 and exhibited antitumor activity. The coumarin-appended bis-formylpyrazoles 4 show antimicrobial and antioxidant activities. ${ }^{21}$ Dai et al. reported $^{22}$ bis-pyrazole molecules $\mathbf{5}$ as antitumor agents. Pyrazole-5-carboxamides 6 were reported for their anti-tobacco mosaic virus activity. ${ }^{23}$ The dipyrazolo-pyranylquinolones 7 were synthesized and evaluated for their antitubercular and antimicrobial activity. ${ }^{24}$ This gave a great impetus for the search of potential pharmacologically active drugs carrying a pyrazole unit in their molecular structure.

1,2,3-Triazole is a well-recognized pharmacophore unit derived from the copper-catalyzed 1,3-dipolar cycloaddition reaction of azides and alkynes. ${ }^{25}$ The increasing impact of click chemistry in the field of medicinal chemistry and drug discovery is due to the high affinity of the triazole scaffold

Received: July 14, 2021

Published: September 13, 2021

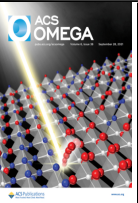


<smiles>[R]C(c1c(C)nn(-c2ccccc2)c1O)c1c(C)nn(-c2ccccc2)c1O</smiles>

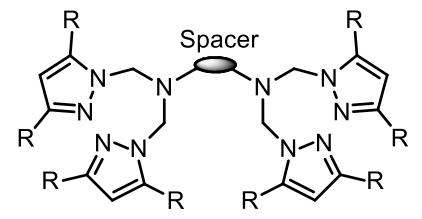

2<smiles>[R]c1nn([Al])cc1C(=O)c1c(C(=O)Nc2ccccc2)nn(-c2ccccc2)c1C</smiles>

3<smiles>[R2]c1cccc(Oc2nn([R])cc2/C=N/O/N=C/c2c(C)nn(C)c2CO)c1-c1c(O)c(-c2nn([R])cc2C)cc2c(C)cc(=O)oc12</smiles><smiles></smiles>

6

7

Figure 1. Structures of the bioactive bis-pyrazole-based molecules.<smiles>NC(=O)c1nnn(Cc2cc(Cl)c(C(=O)c3ccc(Cl)cc3)c(Cl)c2)c1N</smiles>

CAI<smiles>NC(C(=O)NC1C(=O)N2C(C(=O)O)=C(CSc3c[nH]nn3)CS[C@H]12)c1ccc(O)cc1</smiles>

Cefatrizine

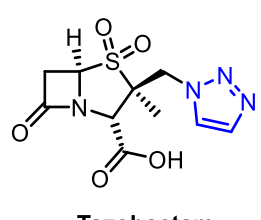

Tazobactam

Figure 2. Structures of 1,2,3-triazole-containing drugs.

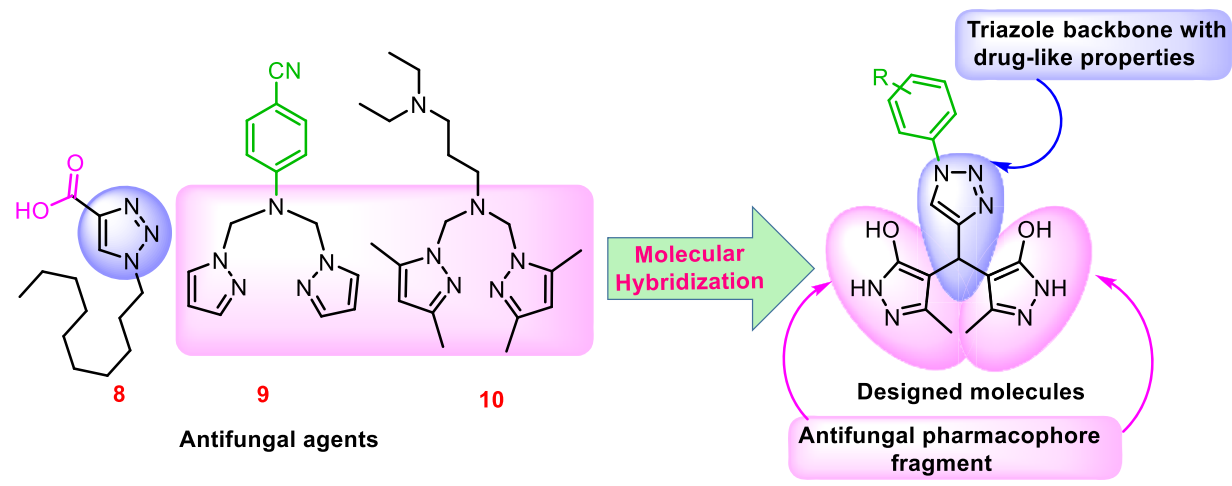

Figure 3. Molecular design strategy of triazole-appended bis-pyrazole derivatives.

toward several therapeutically important biological targets through hydrogen bonding and dipole interactions. ${ }^{26}$ The 1,2,3-triazole pharmacophore unit contains some drugs present in the market, that is, carboxyamidotriazole, cefatrizine, and tazobactam, as shown in Figure 2. Triazole is a medicinally important pharmacophore unit showing various biological activities including antitubercular, ${ }^{27}$ antiproliferative, ${ }^{28}$ antibacterial, ${ }^{29}$ anticancerous, ${ }^{30} \alpha$-glucosidase inhibiting, ${ }^{31}$ antioxidant, $^{32}$ and antifungal ${ }^{33}$ activities.

\section{RESULTS AND DISCUSSION}

2.1. Chemistry. In view of the above and continuation ${ }^{34}$ of our work on the synthesis and bioevaluation of triazole-based bioactive compounds, herein we would like to report 1,2,3triazole-appended bis-pyrazoles and their antifungal, antioxidant activity, and molecular docking study. As an effort toward the design and development of small molecules as antifungal agents, the 1,2,3-triazole-containing molecule $\mathbf{8}^{35}$ and bispyrazole-based molecules $9^{36}$ and $10,{ }^{37}$ we would like to design the molecules by using molecular hybridization approach as shown in Figure 3, which will hopefully display antifungal activity.

The precursor, 1,2,3-triazolyl aldehydes were required for the synthesis of triazole appended bis-pyrazoles and were prepared from corresponding anilines. The anilines were subjected on diazotization, followed by treatment with sodium azide, resulting in respective aryl azides. Theses azides were subjected to the click reaction with propargyl alcohol in $t$ $\mathrm{BuOH}-\mathrm{H}_{2} \mathrm{O}$ that resulted into aryl-1,2,3-triazolyl methanol, which on oxidation with the Collins reagent $\left(\mathrm{CrO}_{3} \cdot 2 \mathrm{Py}\right)$ gave triazolyl aldehydes in moderate yield. ${ }^{34 a, 38}$

Pavlov and co-workers reported the synthesis of bis-pyrazole derivatives in ethanol under reflux conditions; ${ }^{39}$ we have utilized the same method for the synthesis of new 1,2,3triazole-appended bis-pyrazoles. The synthesis of 1,2,3-triazoleappended bis-pyrazole derivatives $13 \mathbf{a}-\mathbf{i}$ was performed by using the appropriate 1,2,3-triazole aldehydes $11 \mathbf{a}-\mathbf{i}$ and 5- 
methyl-2,4-dihydro-3H-pyrazol-3-one 12 in absolute ethanol under reflux conditions in good yields (Scheme 1).

\section{Scheme 1. Synthesis of 1,2,3-Triazole-Appended Bis-} pyrazole Derivatives

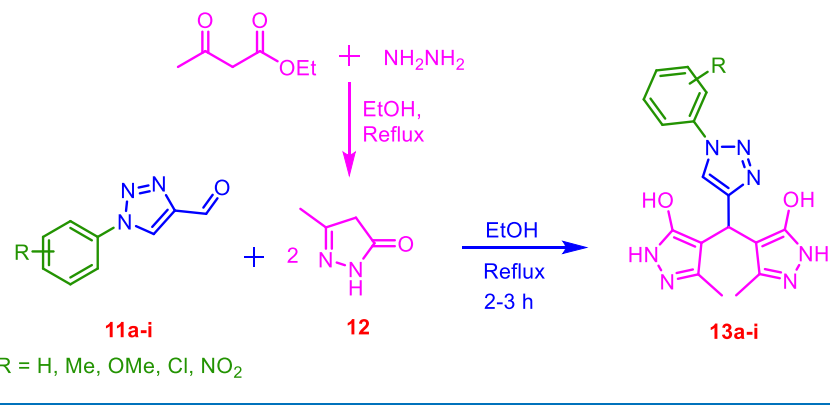

The structures of the newly synthesized 1,2,3-triazoleappended bis-pyrazole derivatives $13 \mathbf{a}-\mathbf{i}$ were confirmed by physical data and spectral analysis. In the ${ }^{1} \mathrm{H}$ NMR spectrum of compound $13 \mathrm{c}$, the singlet signal observed at $\delta 2.13 \mathrm{ppm}$ for six protons corresponded to the methyl groups attached to pyrazole ring. The singlet signal at $\delta 5.02 \mathrm{ppm}$ for one proton was assigned to the methine hydrogen. The singlet signal at $\delta$ $8.07 \mathrm{ppm}$ for one proton was assigned to the triazole hydrogen. The singlet signal at $\delta 3.81 \mathrm{ppm}$ for three protons was assigned to the methoxy group present in the molecule. The ${ }^{13} \mathrm{C}$ NMR spectrum of compound $13 \mathrm{c}$ showed a peak at $\delta 10.9 \mathrm{ppm}$, which was assigned to the methyl carbon on the pyrazole ring. The peak appearing at $\delta 26.3 \mathrm{ppm}$ was assigned to methine carbon, and the peak appearing at $\delta 56.6 \mathrm{ppm}$ was assigned to methoxy carbon. The high-resolution mass spectrometry (HRMS) spectrum of compound 13c shows the calculated mass $(\mathrm{M}+\mathrm{H})$ ion 382.1628 , which is in agreement with the observed mass 382.1633 . The structures of all the synthesized 1,2,3-triazole-appended bis-pyrazole derivatives are shown in Figure 4.

2.2. Biological Evaluation. 2.2.1. Antifungal Activity. The newly synthesized derivatives $13 \mathbf{a}-\mathbf{i}$ were investigated for their in vitro antifungal activity against seven different fungal strains, namely, C. albicans 1 and 2, C. neoformans, Candida glabrata, Candida tropicalis, Aspergillus niger, and A. fumigatus. The results of the antifungal activity are summarized in Table 1. All the synthesized compounds showed excellent antifungal activity against seven fungal strains; however, all compounds exhibited highest activity against $C$. albicans strains. Compounds, 13b, 13e, 13f, and 13i showed excellent antifungal activity with a minimum inhibitory concentration (MIC) value of $4 \mu \mathrm{g} / \mathrm{mL}$, and compounds $13 \mathrm{a}$ and $13 \mathrm{~d}$ showed good antifungal activity with a MIC value of $8 \mu \mathrm{g} / \mathrm{mL}$ against $C$. albicans 1 . Compounds $13 \mathrm{~d}$ and $13 \mathrm{e}$ showed good antifungal activity with an MIC value of $8 \mu \mathrm{g} / \mathrm{mL}$ against C. albicans 2 . Compound 13e showed good antifungal activity with a MIC value of $8 \mu \mathrm{g} / \mathrm{mL}$ against $C$. neoformans. Compound 13f showed good antifungal activity with a MIC value of $8 \mu \mathrm{g} / \mathrm{mL}$

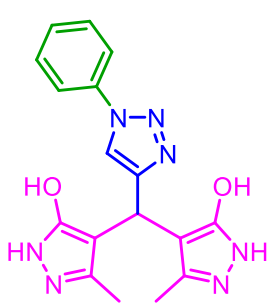

$13 a$

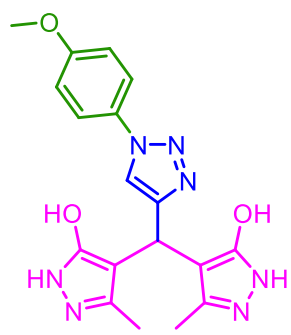

$13 d$

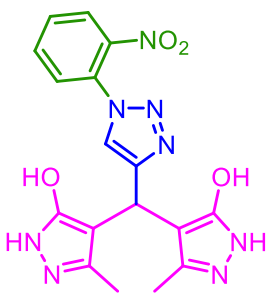

$13 \mathrm{~g}$

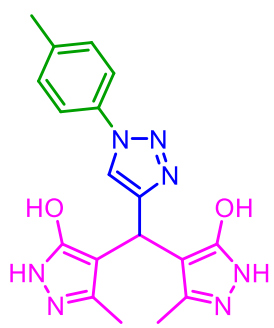

$13 b$<smiles>Cc1n[nH]c(O)c1C(c1cn(-c2cccc(Cl)c2)nn1)c1c(C)n[nH]c1O</smiles>

$13 e$

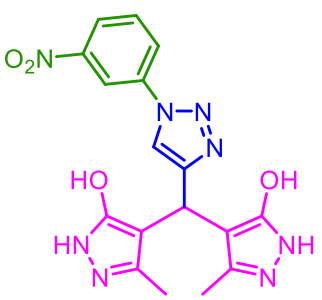

$13 \mathrm{~h}$<smiles>COc1ccccc1-n1cc(C(c2c(C)n[nH]c2O)c2c(C)n[nH]c2O)nn1</smiles>

$13 c$<smiles>Cc1n[nH]c(O)c1C(c1cn(-c2ccc(Cl)cc2)nn1)c1c(C)n[nH]c1O</smiles>

$13 f$<smiles>Cc1n[nH]c(O)c1C(c1cn(-c2ccc([N+](=O)[O-])cc2)nn1)c1c(C)n[nH]c1O</smiles>

$13 i$

Figure 4. Structures of the synthesized 1,2,3-triazole-appended bis-pyrazole derivatives. 
Table 1. In Vitro Antifungal and Antioxidant Activity of 1,2,3-Triazole-Appended Bis-pyrazole Derivatives $13 a-i^{a}$

\begin{tabular}{|c|c|c|c|c|c|c|c|c|}
\hline \multicolumn{8}{|c|}{ antifungal activity $\mathrm{MIC}(\mu \mathrm{g} / \mathrm{mL})$} & \multirow[b]{2}{*}{$\begin{array}{l}\text { antioxidant activity } \mathrm{IC}_{50} \\
(\mu \mathrm{g} / \mathrm{mL})\end{array}$} \\
\hline entry & Candida albicans 1 & Candida albicans 2 & $\begin{array}{l}\text { Cryptococcus } \\
\text { neoformans }\end{array}$ & $\begin{array}{l}\text { Candida } \\
\text { glabrata }\end{array}$ & $\begin{array}{l}\text { Candida } \\
\text { tropicalis }\end{array}$ & $\begin{array}{l}\text { Aspergillus } \\
\text { niger }\end{array}$ & $\begin{array}{l}\text { Aspergillus } \\
\text { fumigatus }\end{array}$ & \\
\hline $13 a$ & 8 & 32 & 32 & 2 & 64 & 32 & 128 & $22.19 \pm 0.87$ \\
\hline $13 b$ & 4 & 16 & 16 & 32 & 64 & 16 & 64 & $27.16 \pm 0.44$ \\
\hline $13 c$ & 16 & 32 & 32 & 32 & 128 & 16 & 128 & $19.12 \pm 0.74$ \\
\hline $13 d$ & 8 & 8 & 32 & 16 & 128 & 128 & 128 & $14.12 \pm 0.32$ \\
\hline $13 e$ & 4 & 8 & 8 & 16 & 32 & 32 & 64 & $17.13 \pm 0.25$ \\
\hline $13 f$ & 4 & 16 & 16 & 8 & 32 & 16 & 32 & $21.15 \pm 0.67$ \\
\hline $13 g$ & 64 & 256 & 256 & 256 & $>256$ & $>256$ & $>256$ & $24.26 \pm 0.76$ \\
\hline $13 \mathrm{~h}$ & 16 & 128 & 32 & 128 & $>256$ & 256 & $>256$ & $17.19 \pm 0.35$ \\
\hline $13 \mathrm{i}$ & 4 & 64 & 16 & 16 & 64 & 32 & $>256$ & $29.34 \pm 0.34$ \\
\hline Flu & 8 & 2 & 32 & 256 & $>256$ & $>256$ & $>256$ & \\
\hline Amp & 2 & 8 & 16 & 128 & $>256$ & 128 & 128 & \\
\hline BHT & & & & & & & & $16.47 \pm 0.18$ \\
\hline
\end{tabular}

${ }^{a}$ Flu: fluconazole, Amp: amphotericin B, BHT: butylated hydroxy toluene, Candida albicans 1 (ATCC 24433), Candida albicans 2 (ATCC 10231), Cryptococcus neoformans (ATCC 34664), Candida glabrata (NCYC 388), Candida tropicalis (ATCC 750), Aspergillus niger (ATCC 10578), Aspergillus fumigatus (NCIM 902).

against C. glabrata. Compound 13a exhibited highest antifungal activity with a MIC value of $2 \mu \mathrm{g} / \mathrm{mL}$ against $C$. glabrata. Also, the remaining compounds from the series showed good to moderate antifungal activity having MIC values of $16,32,64$, and $128 \mu \mathrm{g} / \mathrm{mL}$ against different strains shown in Table 1.

2.2.2. Antioxidant Activity. The antioxidant activity of the synthesized 1,2,3-triazole-appended bis-pyrazole derivatives were evaluated for their in vitro free radical scavenging activity against 2,2-diphenyl-1-picrylhydrazyl (DPPH) free radicals, and the results are summarized in Table 1. Butylated hydroxytoluene (BHT) was used as the standard drug having an $\mathrm{IC}_{50}$ value $16.47 \pm 0.18 \mu \mathrm{g} / \mathrm{mL}$. All the synthesized compounds showed good antioxidant activity in comparison with BHT using the DPPH radical scavenging assay. DPPH is a very stable free radical. For the assay, its solution is prepared in methanol, which produces a purple color. In the assay, DPPH accepts hydrogen from the antioxidant, which acts as the hydrogen bond donor, and as a result of acceptance of hydrogen by DPPH, the intensity of the purple color will be decreased and its concentration is calculated by measuring the absorbance.

Compound 13d exhibited good antioxidant activity with an $\mathrm{IC}_{50}$ value of $14.12 \pm 0.32 \mu \mathrm{g} / \mathrm{mL}$. Compounds $13 \mathrm{c}, 13 \mathrm{e}$, and 13h exhibited good antioxidant activity with $\mathrm{IC}_{50}$ values of $19.12 \pm 0.74,17.13 \pm 0.25$, and $17.19 \pm 0.35 \mu \mathrm{g} / \mathrm{mL}$, respectively. Compounds 13a, 13b, 13f, 13g, and 13i showed good to moderate antioxidant activity with $\mathrm{IC}_{50}$ values of 22.19 $\pm 0.87,27.16 \pm 0.44,21.15 \pm 0.67,24.26 \pm 0.76$, and $29.34 \pm$ $0.34 \mu \mathrm{g} / \mathrm{mL}$, respectively (Table 1 ).

2.3. Computational Studies. 2.3.1. Molecular Docking. In silico techniques such as molecular docking have evolved as an important tool to identify the molecular targets for different ligands, especially in the absence of resources to perform the enzymatic assays. Therefore, such tools have now become an integral part of drug discovery research, imparting knowledge on binding affinities, binding modes, and the associated thermodynamic interactions with the target enzyme that governs the inhibition of the pathogen. The level of antifungal activities demonstrated by the 1,2,3-triazole-appended bispyrazole conjugates $13 \mathbf{a}-\mathbf{i}$ prompted us to perform molecular docking studies to understand the ligand-protein interactions against a crucial target in fungi-sterol $14 \alpha$-demethylase (CYP51). CYP51 is an ancestral active part of the cytochrome P450 superfamily involved in the biosynthesis of an essential component of the fungal cytoplasmic membrane ergosterol. It catalyzes the oxidative removal of the lanosterol $14 \alpha$-methyl group to give $\Delta^{14,15}$-unsaturated intermediates. Inhibition of CYP51 will prevent the conversion of lanosterol to ergosterol, leading to accumulation of $14 \alpha$-methyl sterols, which will consequently impair the cell growth in fungi.

A perusal of the docked complexes of 1,2,3-triazoleappended bis-pyrazole conjugates $13 \mathbf{a}-\mathbf{i}$ showed that they possess a good binding affinity and could snugly fit into the active site of CYP51, adopting a very similar orientation and at coordinates close to the native ligand in the crystal structure. Their docking scores ranged from -9.461 for the active ligand to -6.092 for the least active analogue, while their corresponding binding energy varied from -56.625 to $-48.054 \mathrm{kcal} / \mathrm{mol}$, with each of these molecules engaging in a series of significant bonded ( $\mathrm{H}$-bond and $\pi-\pi$ stacking) and nonbonded (van der Waals and electrostatic) interactions, with the residues lining the active site of the target enzyme. A detailed quantitative investigation of the per-residue bonded and nonbonded interactions between these molecules and the active-site residues of CYP51 was carried out to identify the most significantly interacting residues and the type of interactions which assist in the lead optimization. The results are discussed in detail for the one of the compounds $13 \mathrm{e}$ in the next section, while they are summarized for the remaining molecules in Table 2 for the sake of brevity.

Analysis of the minimum-energy docked conformation of 13e showed that it could snugly fit into the active site of CYP51 at the same coordinates as the native ligand with a significantly higher binding affinity (docking score of -9.461 and binding energy $-56.625 \mathrm{kcal} / \mathrm{mol}$ ) engaging in a series of steric and electrostatic interactions (Figure 5) complemented by a hydrogen bond and $\pi-\pi$ stacking interaction, with the residues forming the active site. Although they are engaged in multiple interactions with the residues in the active site, only selected interacting residues are shown in Figure 5 for the sake of clear visibility.

The most prominent van der Waals (steric) interactions were observed through the two 3-methyl-1H-pyrazol-5-ol 


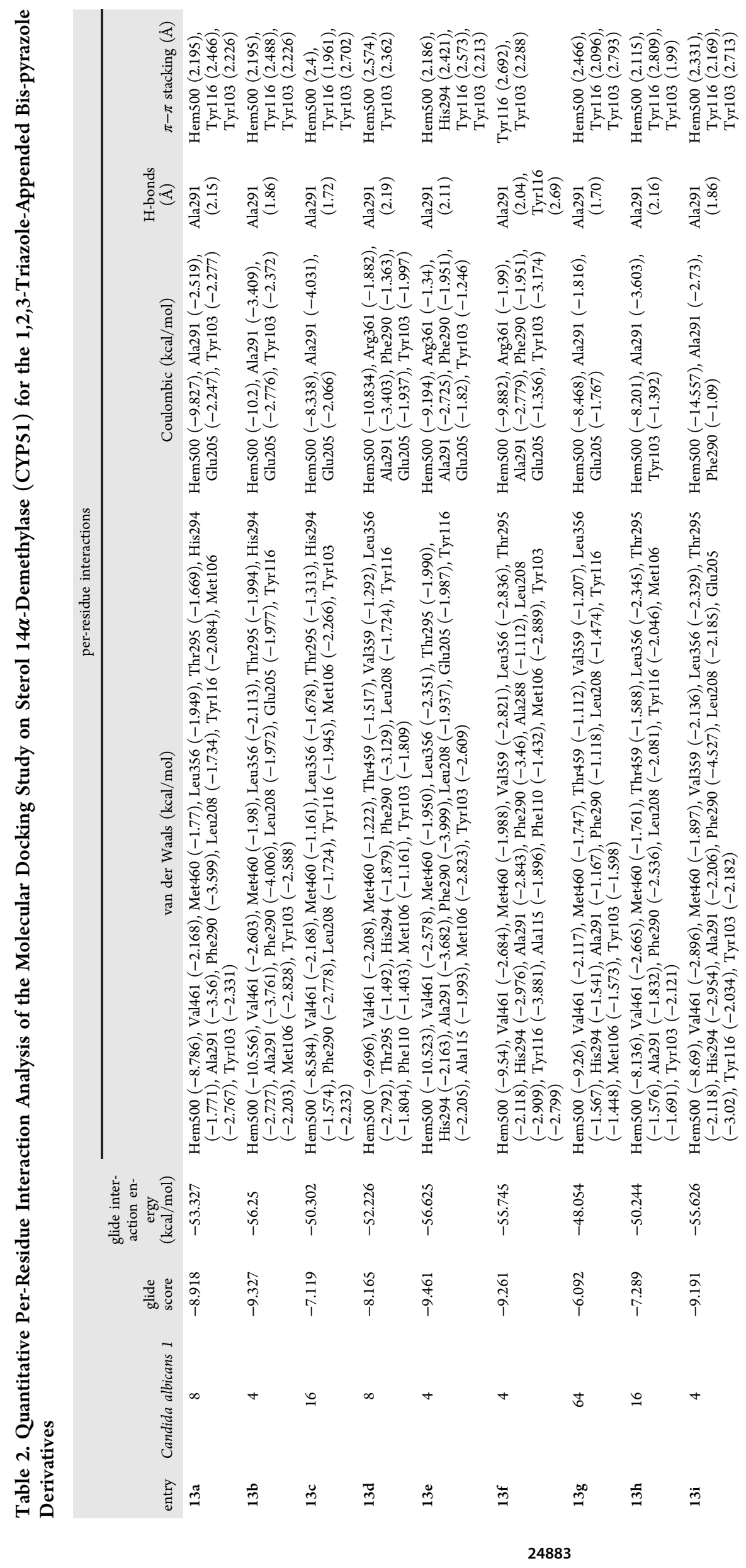




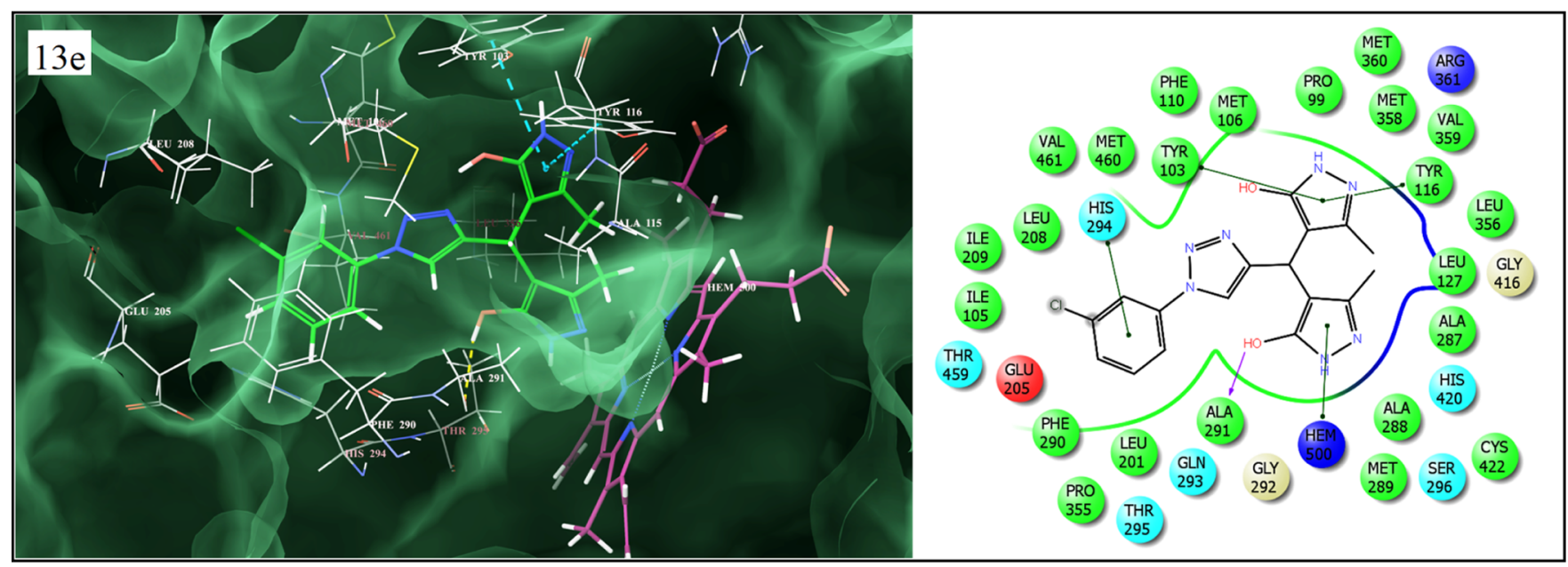

Figure 5. Binding mode of $13 \mathrm{e}$ into the active site of sterol $14 \alpha$-demethylase (CYP51) (on right side: green lines signify $\pi-\pi$ stacking interactions, while the pink lines represent the hydrogen bonding interactions).

scaffolds with Hem500 (-10.523 kcal/mol), Leu356 $(-2.351$ $\mathrm{kcal} / \mathrm{mol})$, Thr295 (-1.990 kcal/mol), Ala291 $(-3.682 \mathrm{kcal} /$ $\mathrm{mol})$, Glu205 $(-1.987 \mathrm{kcal} / \mathrm{mol})$, Tyr116 $(-2.205 \mathrm{kcal} / \mathrm{mol})$, Ala115 (-1.993 kcal/mol), and Tyr103 (-2.609 kcal $/ \mathrm{mol})$, while the 1,2,3-triazole core was observed to be engaged in similar interactions with Val461 $(-2.578 \mathrm{kcal} / \mathrm{mol})$, Met460 $(-1.950 \mathrm{kcal} / \mathrm{mol})$, and Met106 $(-2.823 \mathrm{kcal} / \mathrm{mol})$ residues of the active site. The 3-chlorophenyl side chain as well showed favorable steric interactions with His294 (-2.163 $\mathrm{kcal} / \mathrm{mol})$, Phe290 (-3.999 kcal/mol), and Leu208 (-1.937 $\mathrm{kcal} / \mathrm{mol}$ ) residues. The enhanced binding is also attributed to significant electrostatic interactions observed with Hem500 (-9.194 kcal/mol), Arg361 (-1.34 kcal/mol), Ala291 $(-2.725 \mathrm{kcal} / \mathrm{mol})$, Phe290 (-1.951 kcal/mol), Glu205 $(-1.82 \mathrm{kcal} / \mathrm{mol})$, and Tyr103 $(-1.246 \mathrm{kcal} / \mathrm{mol})$ residues in the active site. Furthermore, the compound was also found to be anchored through a prominent hydrogen bonding interaction through the Ala291 (2.11 $\AA$ ) residue via the hydroxyl $(-\mathrm{OH})$ group of one of the 3-methyl- $1 \mathrm{H}$-pyrazol-5-ol scaffolds. This was further complemented by very strong $\pi-\pi$ stacking interactions with Hem500 (2.186 ̊), Tyr116 (2.573 $\AA$ ), and Tyr103 (2.213 $\AA$ ) through the 3-methyl-1H-pyrazol-5ol while with His294 (2.421 $\AA$ ) through the 3-chlorophenyl side chain. Such bonded interactions (hydrogen bonding and $\pi-\pi$ stacking) anchor the ligand into the active site guiding the $3 \mathrm{D}$ orientation of the ligand and facilitate the steric and electrostatic between the molecule and the enzyme. A similar binding mode and network of well-balanced steric and electrostatic as well as the bonded interactions were involved in stabilizing other molecules in the active site of CYP51 (Figure 6). Overall, the quantitative estimate of the per-residue ligand-receptor interaction suggests that the primary driving force for mechanical interlocking of these molecules is the steric complementarity with the active-site residues of CYP51, as is evident from the relatively higher number of favorable van der Waals interactions than the other components contributing to the binding affinity. This binding information and, more specifically, the per-residue ligand interaction analysis could be fruitfully utilized for the structure-based lead optimization to arrive at potent and more selective antifungal agents targeting CYP51.

2.3.2. In Silico ADME Prediction. In the drug discovery program, $A D M E$ prediction is the first step to check the absorption, distribution, metabolism, and excretion of the novel chemical entities. In the present study, we calculated molecular volume (MV), molecular weight (MW), number of hydrogen bond donors ( $n$-OHNH), number of hydrogen bond acceptors $(n-\mathrm{ON})$, number of rotatable bonds (n-ROTB), logarithm of the partition coefficient $(\operatorname{miLog} P)$, topological polar surface area (TPSA), and Lipinski's rule ${ }^{40}$ of five using a Molinspiration online property calculation toolkit. ${ }^{41}$ The obtained values of ADME prediction are presented in Table 3. The drug-likeness model score was computed by online MolSoft software. ${ }^{42}$ The $\%$ absorption (\% ABS) was calculated using $\% \mathrm{ABS}=109-(0.345 \times$ TPSA $)$.

\section{CONCLUSIONS}

In conclusion, we have synthesized a new series of 1,2,3triazole-appended bis-pyrazole derivatives and evaluated their antifungal and antioxidant activity. Most of the synthesized derivatives exhibited excellent antifungal activity. Compound 13a showed highest antifungal activity with a MIC value of 2 $\mu \mathrm{g} / \mathrm{mL}$ against $C$. glabrata. Compounds, $13 \mathbf{b}, \mathbf{1 3 e}, \mathbf{1 3 f}$, and $13 \mathbf{i}$ exhibited excellent antifungal activity with a MIC value of 4 $\mu \mathrm{g} / \mathrm{mL}$, and compounds 13a and 13d exhibited good antifungal activity with a MIC value of $8 \mu \mathrm{g} / \mathrm{mL}$ against $C$. albicans 1. Compounds $13 \mathrm{~d}$ and $13 \mathrm{e}$ showed a MIC value of 8 $\mu \mathrm{g} / \mathrm{mL}$ against $C$. albicans 2 , and compound $13 \mathrm{e}$ showed a MIC value of $8 \mu \mathrm{g} / \mathrm{mL}$ against $C$. neoformans. Compound $\mathbf{1 3 f}$ showed a MIC value of $8 \mu \mathrm{g} / \mathrm{mL}$ against C. glabrata. The predictions of the molecular docking study were found to be in agreement with the experimental data of the antifungal activity, thereby signifying that the molecules may act as inhibitors of sterol 14 $\alpha$-demethylase (CYP51). The synthesized compound exhibited good antioxidant activity, in comparison with BHT. Compound 13d showed good antioxidant activity with an $\mathrm{IC}_{50}$ value of $14.12 \pm 0.32 \mu \mathrm{g} / \mathrm{mL}$. We expect that 1,2,3-triazole appended bis-pyrazoles can open new opportunities for medicinal research as an antifungal agent.

\section{MATERIALS AND METHODS}

4.1. General Information. All the required chemicals used were purchased from Alfa Aesar, Sigma-Aldrich, and Spectrochem and used without purification. Melting points were obtained on an open-capillary electrothermal melting point apparatus and are uncorrected. Infrared (IR) spectra 

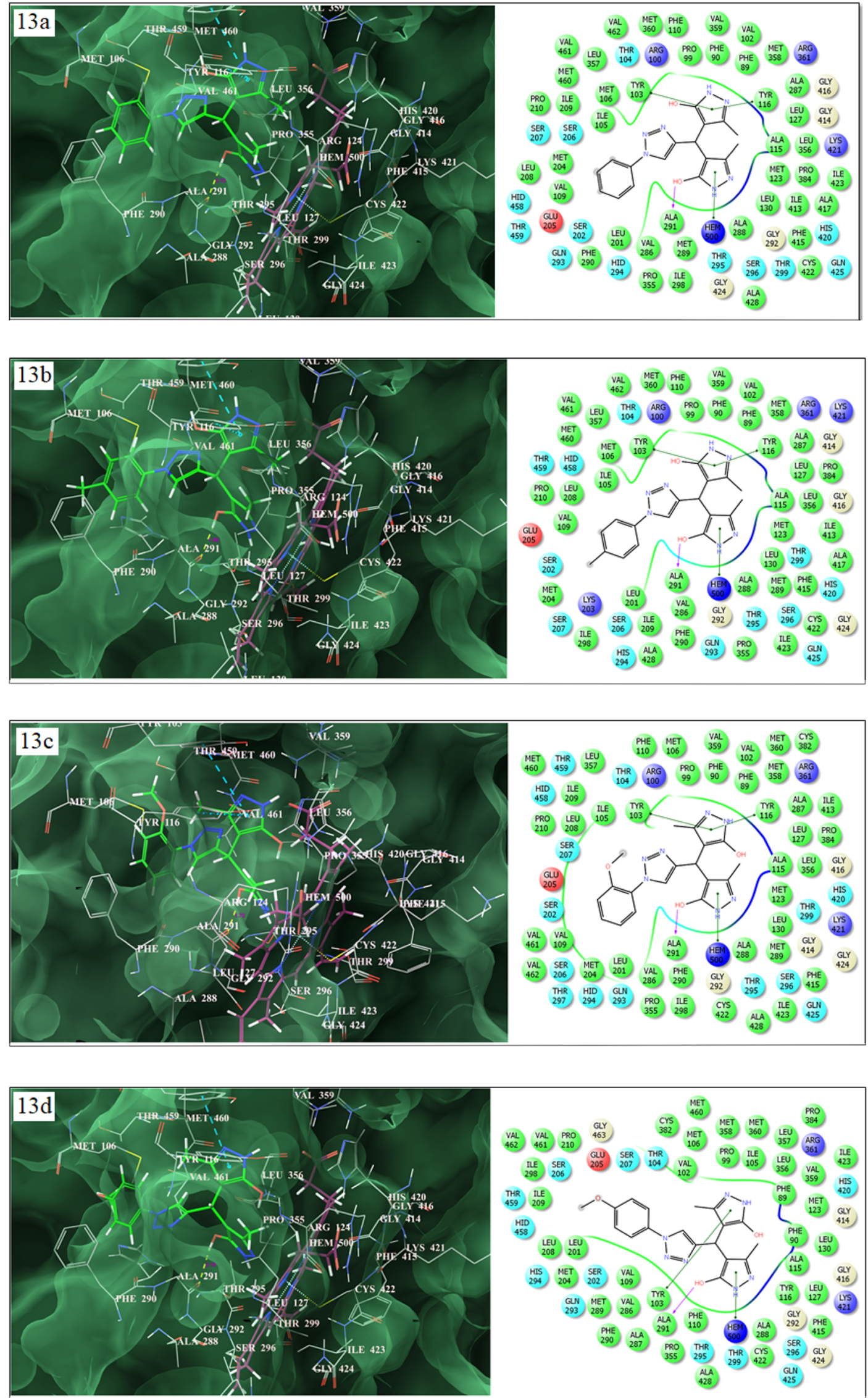

Figure 6. continued 

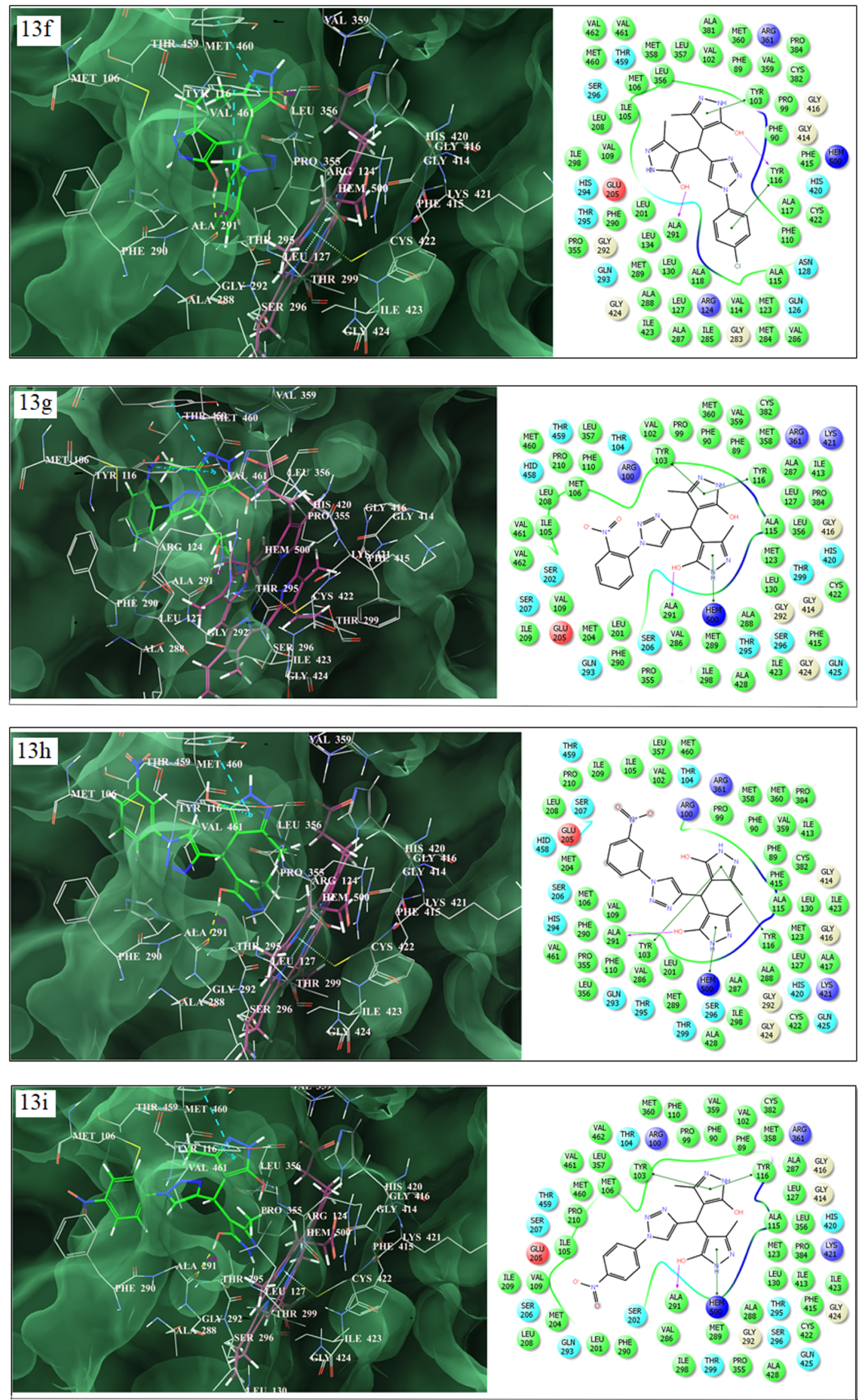

Figure 6. Binding mode of 13a, 13b, 13c, 13d, 13f, 13g, 13h, and 13i into the active site of sterol 14 $\alpha$-demethylase (CYP51) (on right side: green lines signify $\pi-\pi$ stacking interactions, while the pink lines represent the hydrogen bonding interactions). 
Table 3. Pharmacokinetic Parameters Important for Good Oral Bioavailability

\begin{tabular}{|c|c|c|c|c|c|c|c|c|c|c|c|}
\hline entry & $\% \mathrm{ABS}$ & $n$-atoms & TPSA $\left(A^{2}\right)$ & $n$-ROTB & MV & MW & $\operatorname{miLog} P$ & $n$-ON & $n-\mathrm{OHNH}$ & Lipinski's violations & drug-likeness model score \\
\hline rule & & & & & & $<500$ & $\leq 5$ & $<10$ & $<5$ & $\leq 1$ & \\
\hline $13 a$ & 64.653 & 26 & 128.54 & 4 & 302.97 & 351.37 & 1.40 & 9 & 4 & 0 & -0.15 \\
\hline $13 b$ & 64.653 & 27 & 128.54 & 4 & 319.53 & 365.40 & 1.85 & 9 & 4 & 0 & -0.51 \\
\hline $13 c$ & 61.469 & 28 & 137.77 & 5 & 328.51 & 381.40 & 1.62 & 10 & 4 & 0 & -0.25 \\
\hline $13 d$ & 61.469 & 28 & 137.77 & 5 & 328.51 & 381.40 & 1.45 & 10 & 4 & 0 & -0.30 \\
\hline $13 \mathrm{e}$ & 64.653 & 27 & 128.54 & 4 & 316.50 & 385.81 & 2.26 & 9 & 4 & 0 & -0.16 \\
\hline $13 \mathrm{f}$ & 64.653 & 27 & 128.54 & 4 & 316.50 & 385.81 & 2.08 & 9 & 4 & 0 & -0.02 \\
\hline $13 \mathrm{~g}$ & 48.845 & 29 & 174.36 & 5 & 326.30 & 396.37 & 1.52 & 12 & 4 & 1 & -0.01 \\
\hline $13 \mathrm{~h}$ & 48.845 & 29 & 174.36 & 5 & 326.30 & 396.37 & 1.54 & 12 & 4 & 1 & 0.02 \\
\hline $13 i$ & 48.845 & 29 & 174.36 & 5 & 326.30 & 396.37 & 1.36 & 12 & 4 & 1 & -0.01 \\
\hline
\end{tabular}

were measured using an Alpha Bruker Fourier transform infrared (FT-IR) spectrometer. The compounds were confirmed by NMR on a Bruker Avance 500, 400 and 200 $\mathrm{MHz}$ spectrometer. The compounds were solubilized in dimethyl sulfoxide (DMSO)- $d_{6}$ and the tetramethylsilane used as the internal standard. The distortionless enhancement by polarization transfer (DEPT) experiment was used for the assignment of the ${ }^{13} \mathrm{C}$ signals. The HRMS spectra were recorded under electrospray ionization ESI HRMS.

4.2. General Experimental Procedure for the Synthesis of 1,2,3-Triazole-Appended Bis-pyrazole Derivatives $(13 a-i)$. In a round-bottom flask, the bis-pyrazole derivatives $13 \mathbf{a}-\mathbf{i}$ were prepared by refluxing a mixture of triazolyl aldehyde $11 \mathrm{a}-\mathbf{i}(0.5 \mathrm{mmol})$ and 5-methyl-2,4dihydro-3H-pyrazol-3-one $12(1.0 \mathrm{mmol})$ (prepared from ethylacetoacetate and hydrazine hydrate) in absolute ethanol for $2-3 \mathrm{~h}$. The progress of the reaction was monitored by thinlayer chromatography. After completion, the resulting mixture was poured onto $50 \mathrm{~mL}$ of ice water. The obtained solid was filtered, dried, and recrystallized from ethanol-acetic acid to obtain the pure derivatives.

4.2.1. 4,4'-((1-Phenyl-1H-1,2,3-triazol-4-yl)methylene)bis(3-methyl-1H-pyrazol-5-ol) (13a). Yield: $80 \%$ mp: 248-250 ${ }^{\circ} \mathrm{C}$. IR $\nu \mathrm{cm}^{-1}: 3005,2630,1588,1491,1374,1224,1124$, 1047, 989, 756, 683. ${ }^{1} \mathrm{H}$ NMR (500 MHz, DMSO- $\left.d_{6}\right): \delta$ ppm 8.23 (s, 1H), $7.83(\mathrm{~s}, 2 \mathrm{H}), 7.55$ (s, 2H), 7.45 (s, 1H), 5.01 (s, $1 \mathrm{H}), 2.13(\mathrm{~s}, 6 \mathrm{H}) .{ }^{13} \mathrm{C}$ NMR $\left(125 \mathrm{MHz}, \mathrm{DMSO}-d_{6}\right): \delta \mathrm{ppm}$ $161.2,150.8,139.5,137.2,130.3,128.8,120.7,120.4,104.0$, 26.3, 10.8. HRMS: calcd mass $(\mathrm{M}+\mathrm{H})^{+}, 352.1522$; found, 352.1524 .

4.2.2. 4,4'-((1-(p-Tolyl)-1H-1,2,3-triazol-4-yl)methylene)bis(3-methyl-1H-pyrazol-5-ol) (13b). Yield: 83\%. mp: 248$250{ }^{\circ} \mathrm{C}$. IR $\nu \mathrm{cm}^{-1}$ : 3311, 2606, 1593, 1514, 1451, 1275, 1220, 1062, 809, 767, 712. ${ }^{1} \mathrm{H}$ NMR (400 MHz, DMSO- $d_{6}$ ): $\delta$ ppm 8.17 (s, $1 \mathrm{H}), 7.70$ (d, $J=8 \mathrm{~Hz}, 2 \mathrm{H}), 7.34(\mathrm{~d}, J=8 \mathrm{~Hz}, 2 \mathrm{H})$, 4.99 (s, 1H), 2.35 (s, 3H), 2.12 (s, 6H). ${ }^{13} \mathrm{C}$ NMR (100 MHz, DMSO- $\left.d_{6}\right): \delta$ ppm 161.3, 150.6, 139.7, 138.5, 134.9, 130.7, 120.6, 120.3, 104.1, 26.3, 21.0, 10.8 .

4.2.3. 4,4'-((1-(2-Methoxyphenyl)-1H-1,2,3-triazol-4-yl)methylene)bis(3-methyl-1H-pyrazol-5-ol) (13c). Yield: 80\%. mp: $252-254{ }^{\circ} \mathrm{C}$. IR $\nu \mathrm{cm}^{-1}$ : 3307, 2748, 2603, 1605, 1537, 1491, 1463, 1296, 1238, 1169, 1127, 1064, 1023, 848, 780, 753, 705. ${ }^{1} \mathrm{H}$ NMR (400 MHz, DMSO- $d_{6}$ ): $\delta$ ppm 8.07 (s, $1 \mathrm{H}), 7.58(\mathrm{~d}, J=4 \mathrm{~Hz}, 1 \mathrm{H}), 7.48(\mathrm{t}, J=8 \mathrm{~Hz}, 1 \mathrm{H}), 7.28(\mathrm{~d}, J=$ $8 \mathrm{~Hz}, 1 \mathrm{H}), 7.11(\mathrm{t}, J=8 \mathrm{~Hz}, 1 \mathrm{H}), 5.02(\mathrm{~s}, 1 \mathrm{H}), 3.81(\mathrm{~s}, 3 \mathrm{H})$, $2.13(\mathrm{~s}, 6 \mathrm{H}) .{ }^{13} \mathrm{C}$ NMR $\left(100 \mathrm{MHz}\right.$, DMSO- $\left.d_{6}\right): \delta$ ppm 161.2, $151.7,149.4,139.5,130.9,126.3,125.9,124.4,121.5,113.6$, 104.2, 56.6, 26.3, 10.9. HRMS: calcd mass $(\mathrm{M}+\mathrm{H})^{+}$, 382.1628; found, 382.1633 .
4.2.4. 4,4'-((1-(4-Methoxyphenyl)-1H-1,2,3-triazol-4-yl)methylene)bis(3-methyl-1H-pyrazol-5-ol) (13d). Yield: 83\%. mp: $240-242{ }^{\circ} \mathrm{C}$. IR $\nu \mathrm{cm}^{-1}$ : 2589, 1598, 1514, 1462, 1302, 1254, 1182, 1057, 1027, 825, 771, 721, 664. ${ }^{1} \mathrm{H}$ NMR (400 $\left.\mathrm{MHz}, \mathrm{DMSO}-d_{6}\right): \delta \mathrm{ppm} 8.13(\mathrm{~s}, 1 \mathrm{H}), 7.73(\mathrm{~d}, J=8 \mathrm{~Hz}, 2 \mathrm{H})$, $7.08(\mathrm{~d}, J=8 \mathrm{~Hz}, 2 \mathrm{H}), 4.98(\mathrm{~s}, 1 \mathrm{H}), 3.80(\mathrm{~s}, 3 \mathrm{H}), 2.12$ (s, $6 \mathrm{H}) .{ }^{13} \mathrm{C}$ NMR (100 MHz, DMSO-d $): \delta$ ppm 161.2, 159.5, $150.5,139.6,130.7,122.1,120.7,115.3,104.1,56.0,26.3,10.9$.

4.2.5. 4,4'-((1-(3-Chlorophenyl)-1H-1,2,3-triazol-4-yl)methylene)bis(3-methyl-1H-pyrazol-5-ol) (13e). Yield: 82\%. mp: $242-244{ }^{\circ} \mathrm{C}$. IR $\nu \mathrm{cm}^{-1}$ : 3091, 2550, 1657, 1586, 1531, $1467,1378,1234,1151,1046,773,718,671 .{ }^{1} \mathrm{H}$ NMR $(500$ MHz, DMSO- $\left.d_{6}\right): \delta$ ppm $11.28(\mathrm{~s}, 4 \mathrm{H}), 8.34(\mathrm{~s}, 1 \mathrm{H}), 8.02(\mathrm{~s}$, $1 \mathrm{H}), 7.88(\mathrm{~d}, J=10 \mathrm{~Hz}, 1 \mathrm{H}), 7.57(\mathrm{t}, J=10 \mathrm{~Hz}, 1 \mathrm{H}), 7.51(\mathrm{~d}$, $J=10 \mathrm{~Hz}, 1 \mathrm{H}), 5.00(\mathrm{~s}, 1 \mathrm{H}), 2.11(\mathrm{~s}, 6 \mathrm{H}) \cdot{ }^{13} \mathrm{C} \mathrm{NMR}(125$ $\left.\mathrm{MHz}, \mathrm{DMSO}-d_{6}\right): \delta$ ppm 160.8, 150.5, 139.0, 137.8, 134.2, 131.5, 128.1, 120.6, 119.6, 118.4, 103.3, 25.8, 10.4. HRMS: calcd mass $(\mathrm{M}+\mathrm{H})^{+}, 386.1132$; found, 386.1147 .

4.2.6. 4,4'-((1-(4-Chlorophenyl)-1H-1,2,3-triazol-4-yl)methylene)bis(3-methyl-1H-pyrazol-5-ol) (13f). Yield: 80\%. mp: $248-250{ }^{\circ} \mathrm{C}$. IR $\nu \mathrm{cm}^{-1}: 3301,2577,1677,1594,1493$, 1450, 1225, 1058, 988, 826, 769, 703. ${ }^{1} \mathrm{H}$ NMR (400 MHz, DMSO- $\left.d_{6}\right): \delta$ ppm $8.26(\mathrm{~s}, 1 \mathrm{H}), 7.90(\mathrm{~d}, J=8 \mathrm{~Hz}, 2 \mathrm{H}), 7.61$ $(\mathrm{d}, J=8 \mathrm{~Hz}, 2 \mathrm{H}), 5.00(\mathrm{~s}, 1 \mathrm{H}), 2.12(\mathrm{~s}, 6 \mathrm{H}) .{ }^{13} \mathrm{C}$ NMR $(100$ $\left.\mathrm{MHz}, \mathrm{DMSO}-d_{6}\right): \delta$ ppm 161.2, 150.9, 139.6, 136.0, 133.0, $130.3,122.1,120.9,103.9,26.3,10.9$.

4.2.7. 4,4'-((1-(2-Nitrophenyl)-1H-1,2,3-triazol-4-yl)methylene)bis(3-methyl-1H-pyrazol-5-ol) (13g). Yield: 84\%. mp: $230-232{ }^{\circ} \mathrm{C}$. IR $\nu \mathrm{cm}^{-1}$ : 3174, 1666, 1576, 1526, 1476, 1375, 1344, 1291, 1222, 1139, 1088, 1040, 917, 834, 790, 749, 704, 652. ${ }^{1} \mathrm{H}$ NMR (400 MHz, DMSO- $\left.d_{6}\right): \delta$ ppm $8.19(\mathrm{~s}$, $1 \mathrm{H}), 8.15(\mathrm{~d}, J=8 \mathrm{~Hz}, 1 \mathrm{H}), 7.90-7.86(\mathrm{~m}, 1 \mathrm{H}), 7.79-7.75$ $(\mathrm{m}, 2 \mathrm{H}), 5.04(\mathrm{~s}, 1 \mathrm{H}), 2.10(\mathrm{~s}, 6 \mathrm{H}) .{ }^{13} \mathrm{C}$ NMR (100 MHz, DMSO-d $\left.d_{6}\right): \delta$ ppm 161.0, 150.5, 144.5, 139.4, 134.7, 131.2, 129.6, 127.6, 125.9, 123.8, 103.8, 26.3, 10.9 .

4.2.8. 4,4' -((1-(3-Nitrophenyl)-1H-1,2,3-triazol-4-yl)methylene)bis(3-methyl-1H-pyrazol-5-ol) (13h). Yield: $81 \%$. mp: $230-232{ }^{\circ} \mathrm{C}$. IR $\nu \mathrm{cm}^{-1}$ : 3286, 3076, 2895, 2620, 1596, $1536,1469,1344,1299,1228,1147,1090,1050,825,770$, 733, 672. ${ }^{1} \mathrm{H}$ NMR (400 MHz, DMSO- $d_{6}$ ): $\delta$ ppm $8.67(\mathrm{~s}$, $1 \mathrm{H}), 8.49$ (s, 1H), 8.37 (d, $J=8 \mathrm{~Hz}, 1 \mathrm{H}), 8.27$ (d, $J=8 \mathrm{~Hz}$, $1 \mathrm{H}), 7.83(\mathrm{t}, J=8 \mathrm{~Hz}, 1 \mathrm{H}), 5.02(\mathrm{~s}, 1 \mathrm{H}), 2.13(\mathrm{~s}, 6 \mathrm{H}) .{ }^{13} \mathrm{C}$ NMR (100 MHz, DMSO- $\left.d_{6}\right): \delta$ ppm 161.3, 151.3, 149.0, $139.6,137.8,131.9,126.4,123.2,121.4,115.0,103.8,26.3$, 10.9 .

4.2.9. 4,4'-((1-(4-Nitrophenyl)-1H-1,2,3-triazol-4-yl)methylene)bis(3-methyl-1H-pyrazol-5-ol) (13i). Yield: 85\%. mp: $226-228{ }^{\circ} \mathrm{C}$. IR $\nu \mathrm{cm}^{-1}$ : 3332, 3083, 2909, 2600, 1670, $1595,1517,1459,1343,1224,1173,1109,1054,1030,988$, 
851, 758, 680. ${ }^{1} \mathrm{H}$ NMR (500 MHz, DMSO- $d_{6}$ ): $\delta$ ppm 8.41 (s, $1 \mathrm{H}), 8.39$ (d, $J=10 \mathrm{~Hz}, 2 \mathrm{H}), 8.18$ (d, $J=10 \mathrm{~Hz}, 2 \mathrm{H}), 5.00$ $(\mathrm{s}, 1 \mathrm{H}), 2.12(\mathrm{~s}, 6 \mathrm{H}) .{ }^{13} \mathrm{C}$ NMR (50 MHz, DMSO- $\left.d_{6}\right): \delta \mathrm{ppm}$ $160.7,150.9,146.4,140.9,139.3,125.5,120.6,120.3,103.2$, 25.8, 10.3. HRMS: calcd mass $(\mathrm{M}+\mathrm{H})^{+}, 397.1373$; found, 397.1381 .

4.3. Experimental Protocol for Biological Activity. 4.3.1. Microorganisms and Growth Conditions. The human and plant pathogenic fungal strains, C. albicans 1 (ATCC 24433), C. albicans 2 (ATCC 10231), C. tropicalis (ATCC 750), C. glabrata (NCYC 388), C. neoformans (ATCC 34664), A. niger (ATCC 10578), and A. fumigatus (NCIM 902) were obtained from the National Collection of Industrial Microorganisms (NCIM), CSIR-National Chemical Laboratory, Pune, India. The human pathogenic fungal strains were maintained on slopes of YPG agar (yeast extract, 0.3\%; peptone, $0.5 \%$; glucose, $1.0 \%$; agar, $2.0 \%$ ), and filamentous fungi (A. niger and A. fumigatus) were maintained on potato dextrose agar (2\% PDA) slants at $28{ }^{\circ} \mathrm{C}$ and subcultured every 15 days. During experimentation, the fungal strains were grown in YPG broth and diluted to the desired concentration in RPMI 1640 broth.

4.3.2. Determination of the MIC of Compounds. The synthesized compounds were evaluated for antifungal susceptibility testing by the broth microdilution method according to Clinical and Laboratory Standards Institute's broth microdilution methods (CLSI M27-A3) ${ }^{43}$ for yeasts and (CLSI $\mathrm{M} 38-\mathrm{A} 2)^{43}$ for filamentous fungi. The appropriate amounts of test compounds were dissolved in $4 \%$ DMSO to get a $100 \times$ final strength. The stock was then diluted 1:40 in RPMI medium, and $200 \mu \mathrm{L}$ from this was added to the first row of a 96-well microtiter plate. The synthesized compounds were serially diluted twofold in successive wells to get a range of 2$256 \mu \mathrm{g} / \mathrm{mL}$. Yeast cells $\left(\sim 2 \times 10^{4} \mathrm{cfu} / \mathrm{mL}\right.$, spores for phytopathogens), freshly grown in YPG broth in the logarithmic phase, were suspended in the RPMI medium and inoculated $(100 \mu \mathrm{L})$ in the wells of the plate. The microtiter plates were incubated for $24-48 \mathrm{~h}$, and the absorbance was measured at $600 \mathrm{~nm}$ by using a microtiter plate reader to measure the cell growth. $\mathrm{MIC}_{90}$ is defined as the lowest concentration required for $>90 \%$ inhibition of growth with respect to the growth in control.

4.3.3. Antioxidant Activity. 4.3.3.1. 1,1-Diphenyl-1-picrylhydrazyl Radical Scavenging Activity. The bleaching of the purple-colored methanol solution of DPPH radical scavenging activity was used for the determination of the hydrogen atoms or electron donation ability of the compounds. The stable radical DPPH was used as a reagent in the spectrophotometric assay. Next, $1 \mathrm{~mL}$ of various concentrations of the test compounds $(5,10,25,50$, and 100 $\mu \mathrm{g} / \mathrm{mL})$ in methanol was added to $4 \mathrm{~mL}$ of $0.004 \%(\mathrm{w} / \mathrm{v})$ methanol solution of DPPH. After a $30 \mathrm{~min}$ incubation period at room temperature, the absorbance was measured against blank at $517 \mathrm{~nm}$. The percent inhibition (I\%) of free radical production from DPPH was calculated using the following equation

$$
\% \text { of scavenging }=\left[\left(A_{\text {control }}-A_{\text {sample }}\right) / A_{\text {blank }}\right] \times 100
$$

where " $A_{\text {control }}$ " is the absorbance of the control reaction (containing all reagents except the test compound), and " $A_{\text {sample }}$ " is the absorbance of the test compound. Tests were carried out in triplicate.
4.4. Molecular Docking. The molecular docking study was carried out using the Glide (Grid-Based Ligand Docking with Energetics) module incorporated in the Schrodinger molecular modeling package (Schrodinger, LLC, New York, $\mathrm{NY}) .{ }^{44}$ With this purpose, the X-ray crystal structure of sterol $14 \alpha$-demethylase (CYP51) in complex with an inhibitor, fluconazole (PDB code: $3 \mathrm{KHM}$ ), was obtained from the RCSB Protein Data Bank ${ }^{45}$ and refined before subjecting to the docking calculations by running the protein preparation wizard applying the OPLS-2005 force field. This refinement involves eliminating the crystallographically observed water molecules (since they were not conserved in the interaction with the enzyme) by adding the missing side chain and hydrogen atoms corresponding to $\mathrm{pH} 7.0$ considering the appropriate ionization states for the acidic and basic amino acid residues. After assigning the appropriate charge and protonation states, the enzyme structure was subjected to energy minimization until the average root-mean-square deviation reached $0.3 \AA$ to relieve the steric clashes due to addition of hydrogen atoms. The 3D structures of the ligands of 1,2,3-triazole-appended bispyrazole derivatives to be docked were sketched using the build tool in Maestro and then optimized by the Ligand Preparation module which again involves assigning the partial charges using the OPLS-2005 force field and possible ionization states corresponding to a $\mathrm{pH}$ of 7.0 and finally geometry optimization by subjecting to energy minimization until a gradient of 0.001 $\mathrm{kcal} / \mathrm{mol} / \AA$ was reached. Furthermore, using the receptor grid generation tool, the shape and properties of the active site of the enzyme were defined, for which a grid box of $10 \times 10 \times 10$ $\AA$ was generated to include all the amino acid residues within $10 \AA$ of the cocrystallized ligand. With this setting, the optimized protein and ligands were used as input for the docking calculation against the defined active site using an extra-precision (i.e., GlideXP) scoring function to rank the docking poses and to estimate their binding affinities. The output files thus generated as the docking poses were visualized and analyzed for the key thermodynamic elements of interactions with the residues forming the active site using Maestro's Pose Viewer utility.

\section{ASSOCIATED CONTENT}

\section{SI Supporting Information}

The Supporting Information is available free of charge at https://pubs.acs.org/doi/10.1021/acsomega.1c03734.

FT-IR, ${ }^{1} \mathrm{H}$ NMR, ${ }^{13} \mathrm{C}$ NMR, DEPT-NMR, and HRMS spectra of all newly synthesized compounds (PDF)

\section{AUTHOR INFORMATION}

\section{Corresponding Author}

Bapurao B. Shingate - Department of Chemistry, Dr. Babasaheb Ambedkar Marathwada University, Aurangabad 431004 Maharashtra, India; ㅇo orcid.org/0000-00017207-0794; Phone: (91)-240-2403312;

Email: bapushingate@gmail.com; Fax: (91)-240-3335

\section{Authors}

Ashruba B. Danne - Department of Chemistry, Dr. Babasaheb Ambedkar Marathwada University, Aurangabad 431004 Maharashtra, India

Mukund V. Deshpande - Biochemical Sciences Division, CSIR-National Chemical Laboratory, Pune 411008 Maharashtra, India 
Jaiprakash N. Sangshetti - Y. B. Chavan College of Pharmacy, Aurangabad 431001 Maharashtra, India; (1) orcid.org/0000-0002-9064-4111

Vijay M. Khedkar - School of Pharmacy, Vishwakarma University, Pune 411048 Maharashtra, India

Complete contact information is available at: https://pubs.acs.org/10.1021/acsomega.1c03734

\section{Author Contributions}

The manuscript was written through contributions of all authors. All authors have approved the final version of the manuscript.

\section{Notes}

The authors declare no competing financial interest.

\section{ACKNOWLEDGMENTS}

The author A.B.D. is very much grateful to the University Grants Commission (UGC), New Delhi, for the award of research fellowship. The authors are also thankful to the Department of Chemistry, Dr. Babasaheb Ambedkar Marathwada University, Aurangabad, 431 004, India for providing necessary laboratory facilities.

\section{REFERENCES}

(1) Pouliot, M.; Jeanmart, S. Pan Assay Interference Compounds (PAINS) and Other Promiscuous Compounds in Antifungal Research. J. Med. Chem. 2016, 59, 497-503.

(2) Liu, W.; Yuan, L.; Wang, S. Recent Progress in the Discovery of Antifungal Agents Targeting the Cell Wall. J. Med. Chem. 2020, 63, 12429-12459.

(3) Manetti, F.; Castagnolo, D.; Raffi, F.; Zizzari, A. T.; Rajamäki, S.; D'Arezzo, S.; Visca, P.; Cona, A.; Fracasso, M. E.; Doria, D.; Posteraro, B.; Sanguinetti, M.; Fadda, G.; Botta, M. Synthesis of New Linear Guanidines and Macrocyclic Amidinourea Derivatives Endowed with High Antifungal Activity against Candida spp. and Aspergillus spp. J. Med. Chem. 2009, 52, 7376-7379.

(4) Chandrika, N. T.; Shrestha, S. K.; Ngo, H. X.; Tsodikov, O. V.; Howard, K. C.; Garneau-Tsodikova, S. Alkylated Piperazines and Piperazine-Azole Hybrids as Antifungal Agents. J. Med. Chem. 2018, $61,158-173$.

(5) (a) Karrouchi, K.; Radi, S.; Ramli, Y.; Taoufik, J.; Mabkhot, Y.; Al-aizari, F.; Ansar, M. h. Synthesis and Pharmacological Activities of Pyrazole Derivatives: A Review. Molecules 2018, 23, 134. (b) Keter, F. K.; Darkwa, J. Perspective: the potential of pyrazole-based compounds in medicine. BioMetals 2012, 25, 9-21. (c) Naim, M. J.; Alam, O.; Nawaz, F.; Alam, M. J.; Alam, P. Current status of pyrazole and its biological activities. J. Pharm. BioAllied Sci. 2016, 8, 2-17. (d) Alam, M. J.; Alam, O.; Alam, P.; Naim, M. J. A Review on pyrazole chemical entity and biological activity. Int. J. Pharma Sci. Res. 2015, 6, 14331442.

(6) Silva, V. L. M.; Elguero, J.; Silva, A. M. S. Current progress on antioxidants incorporating the pyrazole core. Eur. J. Med. Chem. 2018, 156, 394-429.

(7) El Shehry, M. F.; Ghorab, M. M.; Abbas, S. Y.; Fayed, E. A.; Shedid, S. A.; Ammar, Y. A. Quinoline derivatives bearing pyrazole moiety: Synthesis and biological evaluation as possible antibacterial and antifungal agents. Eur. J. Med. Chem. 2018, 143, 1463-1473.

(8) Xu, Z.; Gao, C.; Ren, Q.-C.; Song, X.-F.; Feng, L.-S.; Lv, Z.-S. Recent advances of pyrazole-containing derivatives as anti-tubercular agents. Eur. J. Med. Chem. 2017, 139, 429-440.

(9) Kumar, G.; Tanwar, O.; Kumar, J.; Akhter, M.; Sharma, S.; Pillai, C. R.; Alam, M. M.; Zama, M. S. Pyrazole-pyrazoline as promising novel antimalarial agents: A mechanistic study. Eur. J. Med. Chem. 2018, 149, 139-147.

(10) El-Gamal, M. I.; Park, B.-J.; Oh, C.-H. Synthesis, in vitro antiproliferative activity, and kinase inhibitory effects of pyrazole- containing diarylureas and diarylamides. Eur. J. Med. Chem. 2018, 156, 230-239.

(11) Shi, J. B.; Tang, W. J.; Qi, X. B.; Li, R.; Liu, X. H. Novel pyrazole-5-carboxamide and pyrazole-pyrimidine derivatives: Synthesis and anticancer activity. Eur. J. Med. Chem. 2015, 90, 889-896.

(12) Chavan, H. V.; Bandgar, B. P.; Adsul, L. K.; Dhakane, V. D.; Bhale, P. S.; Thakare, V. N.; Masand, V. Design, synthesis, characterization and anti-inflammatory evaluation of novel pyrazole amalgamated flavones. Bioorg. Med. Chem. Lett. 2013, 23, 1315-1321.

(13) Ningaiah, S.; Bhadraiah, U. K.; Doddaramappa, S. D.; Keshavamurthy, S.; Javarasetty, C. Novel pyrazole integrated 1,3,4oxadiazoles: Synthesis, characterization and antimicrobial evaluation. Bioorg. Med. Chem. Lett. 2014, 24, 245-248.

(14) Pundeer, R.; Sushma; Kiran, V.; Sharma, C.; Aneja, K. R.; Prakash, O. Synthesis and evaluation of antibacterial and antifungal activities of new ( $Z$ )-3-bromo-4-(1,3-diaryl-1H-pyrazol-4-yl)but-3-en2-ones and 4-(3-methyl-1-phenyl- $1 H$-pyrazol-5-yl)-1,3-diaryl-1 $H$-pyrazoles. Med. Chem. Res. 2013, 22, 4715-4726.

(15) Umesha, B.; Basavaraju, Y. B. Synthesis and characterization of novel benzo $[d][1,3]$ dioxole gathered pyrazole derivatives and their antimicrobial evaluation. Med. Chem. Res. 2014, 23, 3744-3751.

(16) Zhang, A.; Zhou, J.; Tao, K.; Hou, T.; Jin, H. Design, synthesis and antifungal evaluation of novel pyrazole carboxamides with diarylamines scaffold as potent succinate dehydrogenase inhibitors. Bioorg. Med. Chem. Lett. 2018, 28, 3042-3045.

(17) Gouda, M. A. Chemistry of 4,4' -(arylmethylene)-bis (3-methyl1-phenyl-1H-pyrazol-5-ol)s. J. Heterocycl. Chem. 2016, 53, 356-376.

(18) Sujatha, K.; Shanthi, G.; Selvam, N. P.; Manoharan, S.; Perumal, P. T.; Rajendran, M. Synthesis and antiviral activity of $4,4^{\prime}$ (arylmethylene)bis(1H-pyrazol-5-ols) against peste des petits ruminant virus (PPRV). Bioorg. Med. Chem. Lett. 2009, 19, 4501-4503.

(19) Abrigach, F.; Bouchal, B.; Riant, O.; Mace, Y.; Takfaoui, A.; Radi, S.; Oussaid, A.; Bellaoui, M.; Touzani, R. New N,N,N',N'tetradentate Pyrazoly Agents: Synthesis and Evaluation of their Antifungal and Antibacterial Activities. Med. Chem. 2016, 12, 83-89.

(20) Farag, A. M.; Mayhoub, A. S.; Barakat, S. E.; Bayomi, A. H. Regioselective synthesis and antitumor screening of some novel $\mathrm{N}$ phenylpyrazole derivatives. Bioorg. Med. Chem. 2008, 16, 881-889.

(21) Nagamallu, R.; Srinivasan, B.; Ningappa, M. B.; Kariyappa, A. K. Synthesis of novel coumarin appended bis(formylpyrazole) derivatives: Studies on their antimicrobial and antioxidant activities. Bioorg. Med. Chem. Lett. 2016, 26, 690-694.

(22) Dai, H.; Ge, S.; Guo, J.; Chen, S.; Huang, M.; Yang, J.; Sun, S.; Ling, Y.; Shi, Y. Development of novel bis-pyrazole derivatives as antitumor agents with potent apoptosis induction effects and DNA damage. Eur. J. Med. Chem. 2018, 143, 1066-1076.

(23) Zhang, D. Q.; Xu, G. F.; Fan, Z. J.; Wang, D. Q.; Yang, X. L.; Yuan, D. K. Synthesis and anti-TMV activity of novel $N$-(3-alkyl- $1 H$ pyrazol-4-yl)-3-alkyl-4-substituted-1H-pyrazole-5-carboxamides. Chin. Chem. Lett. 2012, 23, 669-672.

(24) Parmar, N. J.; Pansuriya, B. R.; Parmar, B. D.; Barad, H. A. Solvent-free, one-pot synthesis and biological evaluation of some new dipyrazolo $\left[3,4-b: 4^{\prime}, 3^{\prime}-e\right]$ pyranylquinolones and their precursors. Med. Chem. Res. 2014, 23, 42-56.

(25) (a) Kolb, H. C.; Finn, M. G.; Sharpless, K. B. Click Chemistry: Diverse Chemical Function from a Few Good Reactions. Angew. Chem., Int. Ed. 2001, 40, 2004-2021. (b) Thirumurugan, P.; Matosiuk, D.; Jozwiak, K. Click Chemistry for Drug Development and Diverse Chemical-Biology Applications. Chem. Rev. 2013, 113, 4905-4979 and references cited therein. (c) Tiwari, V. K.; Mishra, B. B.; Mishra, K. B.; Mishra, N.; Singh, A. S.; Chen, X. Cu-Catalyzed Click Reaction in Carbohydrate Chemistry. Chem. Rev. 2016, 116, 3086-3240 and references cited therein.

(26) (a) Kolb, H. C.; Sharpless, K. B. The growing impact of click chemistry on drug discovery. Drug Discovery Today 2003, 8, 11281137. (b) Kaur, J.; Saxena, M.; Rishi, N. An Overview of Recent Advances in Biomedical Applications of Click Chemistry. Bioconjugate Chem. 2021, 32, 1455-1471. 
(27) Pradeep Kumar, C. B.; Prathibha, B. S.; Prasad, K. N. N.; Raghu, M. S.; Prashanth, M. K.; Jayanna, B. K.; Alharthi, F. A.; Chandrasekhar, S.; Revanasiddappa, H. D.; Yogesh Kumar, K. Click synthesis of 1,2,3-triazole based imidazoles: Antitubercular evaluation, molecular docking and HSA binding studies. Bioorg. Med. Chem. Lett. 2021, 36, 127810.

(28) Vanaparthi, S.; Bantu, R.; Jain, N.; Janardhan, S.; Nagarapu, L. Synthesis and anti-proliferative activity of a novel 1,2,3-triazole tethered chalcone acetamide derivatives. Bioorg. Med. Chem. Lett. 2020, 30, 127304.

(29) Xu, Z. 1,2,3-Triazole-containing hybrids with potential antibacterial activity against methicillin-resistant Staphylococcus aureus (MRSA). Eur. J. Med. Chem. 2020, 206, 112686.

(30) Sahin, I.; Ozgeris, F. B.; Kose, M.; Bakan, E.; Tumer, F. Synthesis, Characterization, and Antioxidant and Anticancer Activity of 1,4-Disubstituted 1,2,3-triazoles. J. Mol. Struct. 2021, 1232, 130042. (31) Shareghi-Boroujeni, D.; Iraji, A.; Mojtabavi, S.; Faramarzi, M. A.; Akbarzadeh, T.; Saeedi, M. Synthesis, in vitro evaluation, and molecular docking studies of novel hydrazineylideneindolinone linked to phenoxymethyl-1,2,3-triazole derivatives as potential $\alpha$-glucosidase inhibitors. Bioorg. Chem. 2021, 111, 104869.

(32) Joolakanti, H. B.; Kamepalli, R.; Miryala, J.; Battu, S. Synthesis, Docking, and Biological activities of novel Metacetamol embedded [1,2,3]-triazole derivatives. J. Mol. Struct. 2021, 1242, 130786.

(33) (a) Bitla, S.; Gayatri, A. A.; Puchakayala, M. R.; Bhukya, V. K.; Vannada, J.; Dhanavath, R.; Kuthati, B.; Kothula, D.; Sagurthi, S. R.; Atcha, K. R. Design and synthesis, biological evaluation of bis-(1,2,3and 1,2,4)-triazole derivatives as potential antimicrobial and antifungal agents. Bioorg. Med. Chem. Lett. 2021, 41, 128004. (b) Jiang, Z.; Gu, J.; Wang, C.; Wang, S.; Liu, N.; Jiang, Y.; Dong, G.; Wang, Y.; Liu, Y.; Yao, J.; Miao, Z.; Zhang, W.; Sheng, C. Design, synthesis and antifungal activity of novel triazole derivatives containing substituted 1,2,3-triazole-piperdine side chains. Eur. J. Med. Chem. 2014, 82, 490-497. (c) González-Calderón, D.; MejíaDionicio, M. G.; Morales-Reza, M. A.; Ramírez-Villalva, A.; MoralesRodríguez, M.; Jauregui-Rodríguez, B.; Díaz-Torres, E.; GonzálezRomero, C.; Fuentes-Benítes, A. Azide-enolate 1,3-dipolar cycloaddition in the synthesis of novel triazole-based miconazole analogues as promising antifungal agents. Eur. J. Med. Chem. 2016, 112, 60-65. (34) (a) Danne, A. B.; Choudhari, A. S.; Chakraborty, S.; Sarkar, D.; Khedkar, V. M.; Shingate, B. B. Triazole-diindolylmethane conjugates as new antitubercular agents: synthesis, bioevaluation, and molecular docking. Med. Chem. Commun. 2018, 9, 1114-1130. (b) Danne, A. B.; Choudhari, A. S.; Sarkar, D.; Sangshetti, J. N.; Khedkar, V. M.; Shingate, B. B. Synthesis and biological evaluation of novel triazolebiscoumarin conjugates as potential antitubercular and anti-oxidant agents. Res. Chem. Intermed. 2018, 44, 6283-6310. (c) Danne, A. B.; Akolkar, S. V.; Deshmukh, T. R.; Siddiqui, M. M.; Shingate, B. B. One-pot facile synthesis of novel 1,2,3-triazole-appended $\alpha$-aminophosphonates. J. Iran. Chem. Soc. 2019, 16, 953-961. (d) Deshmukh, T. R.; Sarkate, A. P.; Lokwani, D. K.; Tiwari, S. V.; Azad, R.; Shingate, B. B. New amide linked dimeric 1,2,3-triazoles bearing aryloxy scaffolds as a potent antiproliferative agents and EGFR tyrosine kinase phosphorylation inhibitors. Bioorg. Med. Chem. Lett. 2019, 29, 126618. (e) Khare, S. P.; Deshmukh, T. R.; Sangshetti, J. N.; Krishna, V. S.; Sriram, D.; Khedkar, V. M.; Shingate, B. B. Design, Synthesis and Molecular Docking Studies of Novel Triazole-Chromene Conjugates as Antitubercular, Antioxidant and Antifungal Agents. ChemistrySelect 2018, 3, 13113-13122. (f) Akolkar, S. V.; Nagargoje, A. A.; Krishna, V. S.; Sriram, D.; Sangshetti, J. N.; Damale, M.; Shingate, B. B. New $\mathrm{N}$-phenylacetamide-incorporated 1,2,3-triazoles: [ $\left.\mathrm{Et}_{3} \mathrm{NH}\right][\mathrm{OAc}]$ mediated efficient synthesis and biological evaluation. RSC Adv. 2019, 9, 22080-22091. (g) Shaikh, M. H.; Subhedar, D. D.; Arkile, M.; Khedkar, V. M.; Jadhav, N.; Sarkar, D.; Shingate, B. B. Synthesis and bioactivity of novel triazole incorporated benzothiazinone derivatives as antitubercular and antioxidant agent. Bioorg. Med. Chem. Lett. 2016, 26, 561-569. (h) Shaikh, M. H.; Subhedar, D. D.; Nawale, L.; Sarkar, D.; Khan, F. A. K.; Sangshetti, J. N.; Shingate, B. B. 1,2,3-Triazole derivatives as antitubercular agents: synthesis, biological evaluation and molecular docking study. Med. Chem. Commun. 2015, 6, 1104-1116. (i) Shaikh, M. H.; Subhedar, D. D.; Khan, F. A. K.; Sangshetti, J. N.; Shingate, B. B. 1,2,3-Triazole incorporated coumarin derivatives as potential antifungal and antioxidant agents. Chin. Chem. Lett. 2016, 27, 295-301. (j) Shaikh, M. H.; Subhedar, D. D.; Khedkar, V. M.; Jha, P. C.; Khan, F. A. K.; Sangshetti, J. N.; Shingate, B. B. 1,2,3-Triazole tethered acetophenones: Synthesis, bioevaluation and molecular docking study. Chin. Chem. Lett. 2016, 27, 1058-1063.

(35) Fu, N.; Wang, S.; Zhang, Y.; Zhang, C.; Yang, D.; Weng, L.; Zhao, B.; Wang, L. Efficient click chemistry towards fatty acids containing 1,2,3-triazole: Design and synthesis as potential antifungal drugs for Candida albicans. Eur. J. Med. Chem. 2017, 136, 596-602.

(36) Kaddouri, Y.; Abrigach, F.; Ouahhoud, S.; Benabbes, R.; El Kodadi, M.; Alsalme, A.; Al-Zaqri, N.; Warad, I.; Touzani, R. Synthesis, characterization, reaction mechanism prediction and biological study of mono, bis and tetrakis pyrazole derivatives against Fusarium oxysporum $f$. sp. Albedinis with conceptual DFT and ligandprotein docking studies. Bioorg. Chem. 2021, 110, 104696.

(37) Bendaha, H.; Yu, L.; Touzani, R.; Souane, R.; Giaever, G.; Nislow, C.; Boone, C.; El Kadiri, S.; Brown, G. W.; Bellaoui, M. New azole antifungal agents with novel modes of action: Synthesis and biological studies of new tridentate ligands based on pyrazole and triazole. Eur. J. Med. Chem. 2011, 46, 4117-4124.

(38) Boechat, N.; Ferreira, V. F.; Ferreira, S. B.; Ferreira, M. d. L. G.; da Silva, F. d. C.; Bastos, M. M.; Costa, M. d. S.; Lourenço, M. C. S.; Pinto, A. C.; Krettli, A. U.; Aguiar, A. C.; Teixeira, B. M.; da Silva, N. V.; Martins, P. R. C.; Bezerra, F. A. F. M.; Camilo, A. L. S.; da Silva, G. P.; Costa, C. C. P. Novel 1,2,3-Triazole Derivatives for Use against Mycobacterium tuberculosis H37Rv (ATCC 27294) Strain. J. Med. Chem. 2011, 54, 5988-5999.

(39) Pavlov, P. T.; Goleneva, A. F.; Lesnov, A. E.; Prokhorova, T. S. Biological activity of some pyrazolone derivatives. Pharm. Chem. J. 1998, 32, 370-372.

(40) Lipinski, C. A.; Lombardo, F.; Dominy, B. W.; Feeney, P. J. Experimental and computational approaches to estimate solubility and permeability in drug discovery and development settings. Adv. Drug Delivery Rev. 2001, 46, 3-26.

(41) https://www.molinspiration.com/cgi-bin/properties (August 9, 2021).

(42) https://molsoft.com/mprop/ (August 9, 2021).

(43) Clinical and Laboratory Standards Institute. M27-A3, Reference Method for Broth Dilution Antifungal Susceptibility Testing of Yeasts: Approved Standard, 3rd ed., Wayne, PA, 2008. Clinical and Laboratory Standards Institute. M38-A2, Reference Method for Broth Dilution Antifungal Susceptibility Testing of Filamentous Fungi: Approved Standard, 2nd ed., Wayne, PA, 2008.

(44) Friesner, R. A.; Murphy, R. B.; Repasky, M. P.; Frye, L. L.; Greenwood, J. R.; Halgren, T. A.; Sanschagrin, P. C.; Mainz, D. T. Extra Precision Glide: Docking and Scoring Incorporating a Model of Hydrophobic Enclosure for Protein-Ligand Complexes. J. Med. Chem. 2006, 49, 6177-6196.

(45) https://www.rcsb.org/structure/3KHM (February 2, 2019). 